Volume 3. No.2 Agustus 2020 (121-131)

Doi. 10.30596/liabilities.v3i2.5590

\title{
ANALISIS ACTIVITY BASED COSTING SYSTEM SEBAGAI ALTERNATIF PERHITUNGAN TARIF JASA RAWAT INAP PADA RUMAH SAKIT UMUM HAJI MEDAN
}

\author{
Zulia Hanum \\ Andri Wahyudi \\ Program Studi Akuntansi, Fakultas Ekonomi dan Bisnis \\ Universitas Muhammadiyah Sumatera Utara, \\ Email : zuliahanum75@gmail.com
}

\begin{abstract}
ABSTRAK
Perhitungan harga pokok produksi terhadap suatu produk atau jasa sangat penting dilakukan untuk menentukan harga jual, apabila metode perhitungan harga pokok produk atau jasa yang digunakan tidak sesuai untuk diterapkan di era yang modern seperti ini, maka akan terjadi distorsi biaya. Distorsi timbul karena adanya ketidakakuratan dalam pembebanan biaya, sehingga dapat mengakibatkan kesalahan dalam penentuan biaya, pembuatan keputusan, perencanaan dan pengendalian. Tujuan dari penelitian ini adalah untuk mengetahui bagaimana penentuan tarif jasa rawat inap dengan menggunakan activity based costing dan mengetahui besarnya perbandingan tarif jasa rawat inap dengan menggunakan sistem tradisional dan activity based costing system, yang dapat dijadikan acuan dalam menerapkan tarif jasa rawat inap pada Rumah Sakit Umum Haji Medan. Metode analisis yang digunakan adalah metode deskriptif komparatif yaitu menganalisis tarif rumah sakit saat ini, menghitung tarif berdasarkan activity based costing, kemudian membandingkan tarif jasa rawat inap rumah sakit berdasarkan activity based costing dengan realisasinya. Metode pengumpulan data dalam penelitian ini yaitu penelitian kepustakaan, wawancara, dan dokumentasi. Hasil penelitian diketahui bahwa perhitungan menggunakan activity based costing memberikan hasil yang berbeda. Hasil perhitungan dengan menggunakan sistem activity based costing dibandingkan dengan tarif yang ditentukan rumah sakit memberikan hasil yang lebih mahal pada kelas Super VIP, kelas II, dan kelas III. Sedangkan untuk kelas Suite Room, kelas VIP, dan kelas I memberikan hasil yang lebih murah. Perbedaan yang terjadi antara sistem tradisional dan sistem activity based costing disebabkan karena pembebanan biaya overhead pada masing-masing produk tersebut.
\end{abstract}

\section{Kata kunci : Activity Based Costing, Harga Pokok Jasa Rawat Inap Pasien, dan cost driver}

\footnotetext{
ABSTRACT

The calculation of the cost of goods manufactured for a product or service is very important to determine the selling price, if the method of calculating the cost of goods or services used is not suitable to be applied in a modern era like this, then there will be cost distortions. Distortions arise due to inaccuracies in costing, which can result in errors in determining costs, making decisions, planning and controlling. The purpose of this research is to find out how to determine the rate of inpatient services using activity based costing and to know the magnitude of the comparison of inpatient service rates using traditional systems and activity based costing systems, which can be used as a reference in applying inpatient service rates at
} 
General Hospitals Haji Medan. The analytical method used is a comparative descriptive method, namely analyzing the current hospital rates, calculating the rates based on activity based costing, then comparing the hospital inpatient service rates based on activity based costing with its realization. Data collection methods in this study are library research, interviews, and documentation. The results showed that the calculation using activity based costing gave different results. The results of calculations using an activitybased costing system compared to the rates determined by the hospital give more expensive results in the Super VIP, II and III classes. Meanwhile, the Suite Room class, VIP class, and class I provide cheaper results. The difference that occurs between the traditional system and the activity based costing system is due to the imposition of overhead costs on each of these products.

Keywords: Activity Based Costing, Cost of Inpatient Services, and cost drivers

\section{PENDAHULUAN}

Dalam era globalisasi dan ditunjang perkembangan dunia usaha yang semakin pesat, setiap perusahaan saling bersaing dan beradu strategi dalam menarik konsumen, hal ini membuat persaingan di pasar global semakin ketat. Salah satu kunci kesuksesan bersaing dalam pasar bebas adalah perusahaan harus mampu mengelola seluruh potensi yang dimiliki dengan efisien dan efektif. Hal tersebut bukan hanya terjadi pada suatu perusahaan dagang, konstruksi ataupun manufaktur tetapi juga dalam bidang usaha jasa. Salah satu bentuk usaha yang bergerak dibidang jasa kesehatan yaitu jasa rumah sakit. Rumah sakit merupakan suatu organisasi atau perusahaan yang berorientasi non profit atau disebut juga perusahaan nirlaba. Banyak rumah sakit yang berdiri baik dari sektor pemerintah maupun sektor swasta. Tugas utama rumah sakit yaitu memberikan jasa pelayanan kesehatan, pengobatan, dan perawatan. Dalam memberikan jasa pelayanan kesehatan, rumah sakit memperoleh penghasilan dari pendapatan jasa dan fasilitas yang diberikan, salah satunya adalah jasa rawat inap, di mana pendapatan dari jasa tersebut didapat dari tarif yang harus dibayarkan oleh para pemakai jasa rawat inap. Penentuan tarif jasa rawat inap pada rumah sakit merupakan suatu keputusan yang sangat penting, karena penentuan tersebut dapat mempengaruhi profitabilitas suatu rumah sakit. Selama ini pihak Rumah Sakit Umum Haji Medan dalam menentukan harga pokoknya hanya menggunakan sistem biaya tradisional yang penentuan harga pokoknya tidak lagi mencerminkan aktivitas yang spesifik karena banyaknya kategori yang bersifat tidak langsung dan cenderung tetap (fixed), selain itu sistem biaya tradisonal hanya menggunakan satu unit cost driver dan hanya menelusuri biaya ke tempat terjadianya biaya, sehingga penentuan tarif menjadi tidak maksimal dan tidak dapat memberikan informasi biaya yang akurat. Perbedaan utama antara sistem tradisonal dengan sistem activity based costing terletak pada 
jumlah cost driver (pemicu biaya) yang digunakan, dalam penentuan harga pokok produk dengan sistem activity based costing menggunakan cost driver yang lebih banyak di banding dengan sistem biaya tradisional yang hanya menggunakan satu cost driver berdasarkan unit. Sehingga sistem activity based costing melakukan perbaikan dalam pembebanan biaya overhead pabrik kepada produk, yang lebih mencerminkan kegiatan perusahaan dalam memproduksi dan menjual produk. Biaya produk yang dihasilkan oleh sistem tradisional akan memberikan informasi biaya yang terdistorsi. Distorsi timbul karena adanya ketidakakuratan dalam pembebanan biaya, sehingga mengakibatkan kesalahan penentuan biaya, perencanaan, pengendalian dan pembuatan keputusan. Distorsi tersebut juga mengakibatkan undercost/overcost terhadap suatu produk atau jasa.

Activity based Costing merupakan salah satu metode yang menerapkan konsep akuntansi aktivitas untuk menghasilkan perhitungan harga pokok produksi yang lebih akurat. Sistem ABC juga menyediakan informasi tentang biaya-biaya dan kinerja dari setiap aktivitas dan sumber daya serta dapat menelusuri biaya secara akurat ke obyek biaya selain produk, misalnya pelanggan dan saluran distribusi. Menurut Rudianto (2013:160) Activity based costing adalah "pendekatan penentuan biaya produk yang membebankan biaya ke produk atau jasa berdasarkan konsumsi sumber daya oleh aktivitas". Dasar pemikiran pendekatan penentuan biaya ini adalah bahwa produk atau jasa perusahaan dilakukan oleh aktivitas dan aktivitas yang dibutuhkan tersebut menggunakan sumber daya yang menyebabkan timbulnya biaya. Menurut Mulyadi (2014:40) Activity Based Costing yaitu: Sistem informasi biaya yang berorientasi pada penyediaan informasi lengkap tentang aktivitas untuk memungkinkan personel perusahaan melakukan pengolahan terhadap aktivitas. Sistem informasi ini menggunakan aktivitas sebagai basis serta pengurangan biaya dan penentuan secara akurat kos produk/jasa sebagai tujuan.

\section{Konsep-Konsep Activity Based Costing System}

Menurut Rudianto (2013), terdapat dua konsep dasar yang harus diketahui dalam sistem ABC, yaitu:

1. Biaya memiliki penyebab

Biaya ada penyebabnya dan penyebab biaya adalah aktivitas. Dengan demikian, pemahaman yang mendalam tentang aktivitas yang menyebabkan timbulnya biaya akan menempatkan personil perusahaan pada posisi dapat mempengaruhi biaya. Sistem ABC berangkat dari keyakinan dasar bahwa sumber daya menyediakan kemampuan untuk melaksanakan aktivitas, bukan sekedar menyebabkan timbulnya alokasi biaya.

2. Penyebab biaya dapat dikelola Penyebab biaya (yaitu aktivitas) dapat dikelola. Melalui pengelolaan terhadap aktivitas yang menjadi penyebab terjadinya biaya, personil perusahaan dapat memengaruhi biaya. Pengelolaan terhadap aktivitas memerlukan berbagai informasi tentang aktivitas. 


\section{Manfaat Penerapan Activity Based Costing System}

Manfaat penerapan sistem ABC menurut Ahmad Dunia dan Wasilah (2012:331), yaitu:

1. Membantu mengidentifikasi ketidakefisienan yang terjadi dalam proses produksi, baik per departemen, per produk ataupun peraktivitas. Hal ini mungkin dilakukan dengan proses $\mathrm{ABC}$, mengingat penerapan sistem ABC harus dilakukan melalui analisis atas aktivitas yang terjadi di seluruh perusahaan.

2. Membantu pengambilan keputusan dengan baik karena perhitungan biaya atas suatu objek biaya menjadi lebih baik karena perhitungan biaya atas suatu objek biaya menjadi lebih akurat, hal ini disebabkan karena perusahaan lebih mengenal perilaku biaya overhead pabrik dan dapat membantu mengalokasikan sumber daya yang dimiliki perusahaan untuk objek yang lebih menguntungkan.

3. Membantu mengendalikan biaya (terutama biaya overhead pabrik) kepada level individual dan level departemental. Hal ini dapat dilakukan mengingat $\mathrm{ABC}$ lebih focus pada biaya per unit (unit cost) dibandingkan total biaya.

\section{Perbandingan Sistem Biaya Tradisional dengan Activity Based Costing}

Sistem biaya tradisional adalah sistem yang terdiri dari dua tahap, yaitu tahap pertama biayabiaya tidak dilacak ke aktivitas melainkan ke suatu unit organisasi misalnya pabrik atau departemen.
Sedangkan sistem activity based costing juga memiliki dua tahap, akan tetapi pada tahap pertama melacak biaya pada berbagai aktivitas. Baik pada sistem tradisioanl maupun activity based costing, pada tahap kedua meliputi pelacakan biaya ke berbagai produk. Perbedaan sistem perhitungan dari kedua metode tersebut adalah jumlah cost driver yang digunakan. Sistem activity based costing penentuan harga pokoknya dengan menggunakan cost driver yang lebih banyak dibandingkan dengan sistem tradisional yang hanya menggunakan satu atau dua cost driver berdasarkan unit.

\section{Kerangka Berfikir}

Dalam menentukan harga pokok dengan metode tradisional akan membebankan semua biaya yang dialokasikan berdasarkan unit yaitu hari rawat inap. Sistem biaya tradisional tersebut tidak akurat dan cenderung menghasilkan biaya produk yang lebih besar, karena sistem biaya tradisional hanya berfokus pada kuantitas produk atau unit produk dalam menentukan harga pokok Sedangkan penentuan harga pokok rawat inap menggunakan metode $A B C$ yaitu menelusuri biaya berdasarkan aktivitas, yang dikelompokkan menjadi 3 aktivitas yaitu aktivitas hunian, aktivitas makan dan minum, dan aktivitas perawatan.Aktivitas-aktivitas tersebut akan mengkonsumsi berbagai sumber daya yang tersedia yaitu, dokter, perawat, fasilitas, gedung, listrik, air, tenaga kebersihan, laundry, administrasi, makan dan minum, lalu jumlah sumber daya yang dikonsumsi oleh aktivitas-aktivitas dihitung berdasarkan cost driver, misalnya 
jumlah hari rawat inap, KWh, jam perawatan, luas bangunan, dan jumlah pasien. Maka akan dihasilkan perhitungan harga pokok produksi yang lebih tepat dan teliti.

Hasil dari perhitungan harga pokok produksi atau tarif rawat inap menggunakan sistem Activity Based Costing akan dibandingkan dengan tarif rawat inap rumah sakit yang telah diterapkan sebelumnya. Kemudian hasil dari perbandingan antara dua harga pokok tersebut selanjutnya akan dianalisis untuk mengetahui relevan atau tidaknya jika diterapkan di rumah sakit tersebut.

Berdasarkan uraian yang telah dikemukakan, maka dapat digambarkan sebagai berikut :

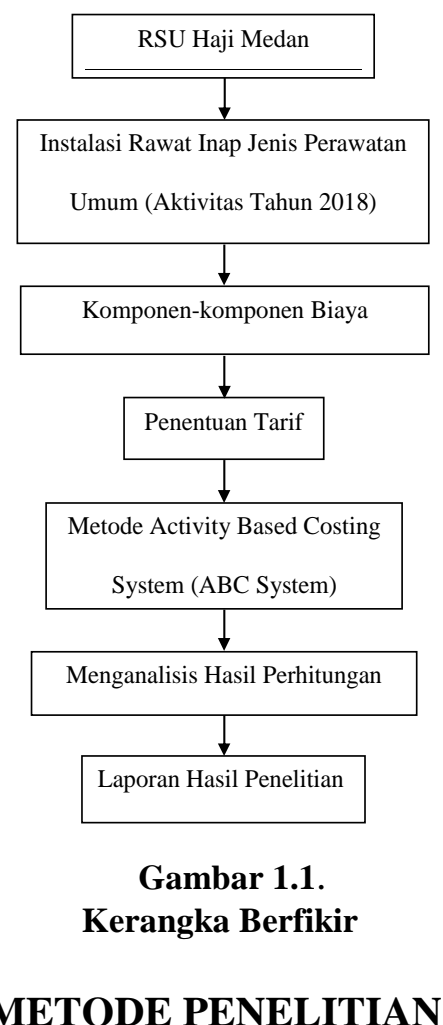

\section{Jenis Penelitian}

Jenis penelitian ini merupakan jenis penelitian deskriptif komparatif yaitu penelitiandengan cara mengumpulkan data, menyusun data, mengklasifikasi data, dan menguraikan data sehingga data yang dikumpulkan dapat menginformasikan gambaran kondisi perusahaan yang jelas mengenai masalah yang akan diteliti. Kemudian membandingkannya dengan kondisi, situasi ataupun variabel yang diterapkan oleh objek penelitian, sehingga nantinya dapat dijadikan sebagai dasar dalam penetapan tarif untuk jasa rawat inap kamar pada Rumah Sakit Umum Haji Medan.

\section{Teknik Pengumpulan Data}

Teknik pengumpulan data dalam penelitian ini adalah :

1. Penelitian Kepustakaan (Library Research) yaitu teknik pengumpulan data dari berbagai literatur,referensi dan hasil penelitian yang berhubungan dengan obyek penelitian. Tujuannya adalah untuk memperoleh pengetahuan dan wawasan yang dijadikan acuan untuk melakukan analisis dan menunjang pembahasan masalah dalam penelitian ini.

2. Penelitian Lapangan (Field Research) yaitu penelitian yang dilakukan dengan pengamatan secara langsung tempat yang menjadi objek penelitian, guna untuk memperoleh informasi dan gambaran mengenai permasalahan yang akan dibahas dalam penelitian ini. Penelitian ini dilaksanakan dengan cara sebagai berikut :

a. Metode Wawancara

Dalam penelitian ini metode wawancara yang digunakan adalah jenis tidak terstruktur yang ditujukan pada bagian yang berhubungan dengan penelitian ini sebagai upaya 
pengumpulan data yang meliputi informasi mengenai jenis jenis pelayanan kesehatan dan kebijakan yang digunakan dalam perhitungan harga pokok jasa rawat inap pasien pada Rumah Sakit Umum Haji Medan.

b. Metode Dokumentasi

Dalam penelitian ini metode dokumentasi digunakan untuk mengumpulkan data-data berupa tarif kamar yang diterapkan, nama ruang dan kelas rawat inap, jumlah hari rawat inap, jumlah tempat tidur, biaya pelayanan medis dan biaya-biaya lainnya yang berkaitan dengan perhitungan tarif rawat inap pada Rumah Sakit Umum Haji Medan. Data-data tersebut diperoleh dari bidang-bidang yang terkait seperti bidang keuangan, bidang instalasi gizi, bidang pelayanan, dan bidang umum.

\section{Teknik Analisis Data}

Dalam penelitian ini, teknik analisis data yang digunakan adalah metode analisis deskriptif komparatif. Data yang diperlukan yaitu tentang aktivitas-aktivitas biaya rawat inap. Setelah pengumpulan data selesai, maka dilakukan penghitungan harga pokok atau tarif rawat inap dengan menggunakan sistem Activity Based Costing sebagai berikut :

1. Mengidentifikasi dan menggolongkan biaya ke dalam berbagai aktivitas.

2. Mengklasifikasikan aktivitas biaya ke dalam berbagai aktivitas, pada langkah ini biaya-biaya dikelompokkan kedalam berbagai aktivitas yang terdiri dari 4 kategori, yaitu unit level activity costing, batch related activity costing, product sustaining activity costing, facility sustaining activity costing.

3. Mengidentifikasikan cost driver

Pengidentifikasian cost driver dimaksudkan untuk memudahkan dalam penentuan tarif per unit cost driver

4. Menentukan tarif perunit cost driver

Biaya per unit cost driver yang dihitung untuk suatu aktivitas. Tarif per unit cost driver menurut Hansen dan Mowen (2013:162) dapat dihitung dengan rumus :

$$
\text { Taif per urit cost ćiver }=\frac{\text { jurleh akavitas }}{\text { cost civiver }}
$$

5. Membebankan biaya ke produk dengan menggunakan tarif cost driver dan ukuran aktivitas.

a. Pembebanan biaya overhead dari tiap aktivitas ke setiap kamar dihitung dengan rumus sebagai berikut:

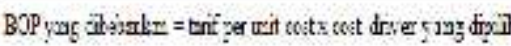

b. Kemudian perhitungan tarif masing-masing tipe kamar dengan metode activity based costing dapat dihitung dengan rumus sebagai berikut:

Taif per k:mar= cct rewatinap - laja yang dihareplan

6. Membandingkan perhitungan tarif jasa rawat inap berdasarkan sistem. 


\section{HASIL DAN PEMBAHASAN PENELITIAN}

\section{Penentuan Harga Pokok Tarif Jasa Rawat Inap Menggunakan Activity Based Costing System}

\section{Mengidentifikasi dan Mendefinisikan Aktivitas dan Pusat Aktivitas}

Berdasarkan hasil data yang didapatkan dari bagian keuangan, bagian instalasi gizi, bagian rekamedik, dan bagian inventaris/rumah tangga. Aktivitasaktivitas biaya yang ada dalam unit rawat inap, yaitu :

1. Aktivitas perawatan pasien terdiri dari biaya gaji tenaga medis

2. Aktivitas pemeliharaan inventaris terdiri dari biaya penyusutan gedung, biaya penyusutan fasilitas, biaya kebersihan, biaya pemeliharaan alat dokter

3. Aktivtas pemeliharaan pasien terdiri dari biaya konsumsi

4. Aktivitas pelayanan pasien terdiri dari biaya administrasi, biaya listrik dan air, biaya laundry, biaya bahan habis pakai

\section{Mengklasifikasi Aktivitas Biaya ke Dalam Berbagai Aktivitas}

1. Berdasarkan Unit Level Activity Cost

Aktivitas ini dilakukan setiap hari oleh rumah sakit dalam menjalani rawat inap pada pasien. Aktivitas yang tergolong Klasifikasi biaya kedalam berbagai aktifitas dapat dilihat pada tabel 1: dalam kategori ini yaitu aktivitas tenaga medis, aktivitas penggunaan tenaga listrik dan air, aktivitas konsumsi, dan aktivitas laundry.

2. Berdasarkan Batch Related Activity Cost

Biaya ini tergantung pada frekuensi order produksi yang diolah oleh fungsi produksi. Aktivitas ini tergantung dari jumlah batch produk yang di produksi, seperti biaya administrasi, biaya bahan habis pakai, biaya kebersihan.

3. Berdasarkan Product Sustaining Activity Cost

Aktivitas ini berhubungan dengan proses pengembangan produk tertentu dan penelitian serta biaya-biaya untuk mempertahankan suatu produk agar tetap dapat dipasarkan. Aktivitas ini tidak terdapat pada penentuan tarif jasa rawat inap pada Rumah Sakit Umum Haji Medan.

4. Berdasarkan Facility Sustaining Activity Cost Aktivitas ini merupakan kegiatan untuk mempertahankan fasilitasfasilitas yang dimiliki oleh perusahaan. Aktivitas yang termasuk dalam kategori ini adalah penyusutan fasilitas dan penyusutan gedung. 
Volume 3. No.2 Agustus 2020 (121-131)

Doi. 10.30596/liabilities.v3i2.5590

Tabel 1

Klasifikasi Biaya Ke Dalam Berbagai Aktivitas

\begin{tabular}{|c|c|c|}
\hline \multicolumn{3}{|c|}{ Unit Level Activity Cost } \\
\hline $\begin{array}{l}\text { Biaya Gaji Tenaga } \\
\text { Medis }\end{array}$ & $\mathrm{Rp}$ & 7.692.226.374 \\
\hline Biaya Listrik & $\mathrm{Rp}$ & 287.303 .523 \\
\hline Biaya Air & $\mathrm{Rp}$ & 218.992 .630 \\
\hline Biaya Konsumsi & $\mathrm{Rp}$ & 1.744 .909 .000 \\
\hline Biaya Laundry & $\mathrm{Rp}$ & 186.450 .000 \\
\hline \multicolumn{3}{|c|}{ Batch Related Activity Cost } \\
\hline Biaya Kebersihan & $\mathrm{Rp}$ & 351.362 .156 \\
\hline Biaya Administrasi & $\mathrm{Rp}$ & 53.597 .500 \\
\hline $\begin{array}{l}\text { Biaya Bahan Habis } \\
\text { Pakai }\end{array}$ & $\mathrm{Rp}$ & 262.576 .590 \\
\hline \multicolumn{3}{|c|}{ Facility Sustaining Activity Cost } \\
\hline $\begin{array}{l}\text { Biaya Penyusutan } \\
\text { Gedung }\end{array}$ & $\mathrm{Rp}$ & 179.754 .950 \\
\hline $\begin{array}{l}\text { Biaya Penyusutan } \\
\text { Fasilitas }\end{array}$ & $\mathrm{Rp}$ & 144.427 .876 \\
\hline $\begin{array}{l}\text { Biaya Pemeliharaan } \\
\text { Alat Dokter }\end{array}$ & $\mathrm{Rp}$ & 195.299 .908 \\
\hline TOTAL & $\mathrm{Rp}$ & 11.347 .900 .507 \\
\hline
\end{tabular}

Sumber : Data yang diolah

\section{Mengidentifikasi Cost Driver}

Setelah aktivitas-aktivitas tersebut di identifikasi berdasarkan kategorinya, langkah selanjutnya yaitu mengidentifikasi cost driver (pemicu biaya) dari setiap biaya aktivitas-aktivitas.

Pengidentifikasian ini bertujuan untuk menentukan kelompok aktivtas dan tarif/unit cost driver.

\section{Menentukan Tarif Per Unit Cost Driver}

Menurut Hansen dan Mowen (2013:162) tarif per unit cost driver dapat dihitung dengan rumus :

Tarif per unit cost driver $=\frac{\text { Jumlah aktivitas }}{\text { Cost Driver }}$

Berikut ini penentuan tarif per unit cost driver kamar rawat inap pada rumah sakit dengan metode Activity Based Costing.

\section{Membebankan Biaya Ke Produk Dengan Menggunakan Tarif Cost Driver dan Ukuran Aktivitas}

Dalam tahap ini, biaya aktivitas dibebankan ke produk berdasarkan konsumsi masing-masing aktivitas produk. Biaya overhead yang dibebankan dari aktivitas ke setiap kamar dapat dihitung dengan rumus sebagai berikut : 


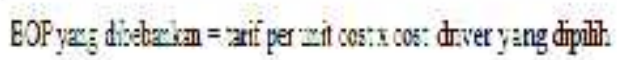

Setelah mengetahui BOP yang dibebankan pada masing-masing produk, maka dapat menghitung tarif tarif jasa rawat inap per kamar dengan rumus :

Taníperkamar $=$ cost rawatimap + laba yang dir:arap'san

Untuk cost rawat inap per kamar diperoleh dari total biaya yang telah dibebankan pada masing-masing produk dibagi dengan jumlah hari pakai pasien per kamar, dan laba yang diharapkan ditetapkan pihak manajemen rumah sakit yaitu kelas Suite Room 30\%, kelas Super VIP $26 \%$, kelas VIP 25\%, kelas I 23\%, kelas II 13\%, kelas III 5\%. Dari perhitungan dapat dilihat bahwa hasil perhitungan tarif jasa rawat inap dengan mengunakan sistem activity based costing untuk kelas Suite Room Rp. 946.001, kelas Super VIP Rp. 825.251, kelas VIP Rp. 400.413, kelas I Rp. 348.810, kelas II Rp. 308.241, kelas III Rp. 243.117. Dari hasil tersebut terdapat selisih yang berbeda dari setiap kelas kamar rawat inap, dengan selisih untuk kelas Suite Room Rp. 153.001, kelas Super VIP Rp. 75.251, kelas VIP Rp. 174.587, kelas I Rp. 61.190, kelas II Rp. 78.241, kelas III Rp. 85.617. Perbedaan yang terjadi antara sistem tradisional dan sistem activity based costing untuk tarif jasa rawat inap disebabkan karena pembebanan biaya overhead pada masing-masing produk. Pada sistem tradisional biaya overhead pada masing-masing produk hanya dibebakan pada satu cost driver saja. Hal tersebut mengakibatkan terjadinya distorsi pada pembebanan biaya overhead, sedangkan pada sistem activity based costing, biaya overhead pada masing-masing produk dibebankan pada banyak cost driver. Sehingga dalam sistem activity based costing mampu untuk mengalokasikan biaya-biaya aktivitas ke setiap kamar rawat inap berdasarkan konsumsi masing-masing aktivitas tersebut.

\section{KESIMPULAN DAN SARAN}

\section{Kesimpulan}

Berdasarkan hasil penelitian dapat disimpulkan bahwa dari hasil perhitungan tarif jasa rawat inap dengan menggunakan sistem activity based costing apabila dibandingkan dengan tarif rawat inap yang ditentukan Rumah Sakit Umum Haji Medan saat ini, maka sistem activity based costing memberikan hasil yang lebih mahal pada kelas Super VIP, kelas II, dan kelas III. Dengan selisih untuk kelas Super VIP sebesar Rp. 75.251, kelas II sebesar Rp. 78.241, dan kelas III sebesar Rp. 85.617. Sedangkan untuk kelas Suite Room, kelas VIP, dan kelas I sistem activity based costing memberikan hasil yang lebih murah, dengan selisih kelas Suite Room sebesar Rp. 153.001, kelas VIP sebesar Rp. 174.587, dan kelas I sebesar Rp. 61.190.

\section{Saran}

Berdasarkan kesimpulan di atas pihak manajemen rumah sakit dapat mempertimbangkan perhitungan tarif jasa rawat inap dengan menggunakan 
e-ISSN 2620-5866

Volume 3. No.2 Agustus 2020 (121-131)

Doi. 10.30596/liabilities.v3i2.5590

activity based costing system dan tetap mempertimbangkan faktor-faktor eksternal seperti tarif pesaing dan keadaan sosial masyarakat umum.

\section{DAFTAR PUSTAKA}

Astuty, Widia. (2016). Akuntansi Manajemen. Medan: Perdana Publishing.

Blocher, dkk. (2011). Manajemen Biaya Penekanan Strategis. Jakarta: Salemba Empat.

Dewi,SP, Septian Bayu. (2017). Akuntansi Biaya. Penerbit In Media Bogor.

Fakultas, A., Universitas, E., \& Nusantara, M. (n.d.). PENERAPAN ACTIVITY BASED COSTING SYSTEM DALAM MENENTUKAN HARGA POKOK ( Studi Kasus Penentuan Besarnya Tarif Jasa Rawat Inap Pada RSUD Deli Serdang Lubuk Pakam ). 103-117.

Fakultas Ekonomi dan Bisnis. (2019).

Pedoman Penulisan Skripsi. http//www.febumsu.ac.id. Diakses

28 Desember 2019.

Firdaus, Ahmad dan Wasilah. (2009). Akuntansi Biaya. Jakarta: Salemba Empat.

Hansen, Don R. Maryanne M Mowen. Management Accounting, 7th. Diterjemahkan oleh Tim Penerjemah Penerbit Salemba Empat dengan judul Akuntansi Manajemen, Edisi 7. Buku 1. Salemba Empat : Jakarta, 2004

Ikhsan, Arfan. (2014). Metodologi Penelitian Bisnis. Penerbit Citapustaka Media Bandung.

Ilmiah, J., Issn, E. I. A. P. dalam P. H. J. pada P. C. C. B. I. M., \& ZULIA HANUM Jurnal. (2013). Sistem Informasi Akuntansi Penuh dalam Penentuan Harga Jual pada PT. Coca Cola Bottling Indonesia Medan ZULIA HANUM. Jurnal Ilmiah Ekonomikawan.

Kesehatan, Departemen. (2003). Keputusan Menteri Kesehatan Republik Indonesia Nomor 560/MENKES/SK/IV/2003, [pdf], (http://www.depkes.go.id/downloa ds/Sk560-03.pdf, diakses pada tanggal 30 Desember 2019)

Khaddafi, Muammar, dkk. (2017). Akuntansi Biaya (A. Ikhsan (ed.)). Penerbit Madenatera.

Miranti, B., \& Triharyati, E. (2015). Analisis Penentuan Tarif Rawat Inap Dengan Metode Activity Based Costing Pada Rsud Hapsari Medika. Jurnal Ilmu Manajemen, 5(1), 28-43.

Najah, N., Raharjo, K., \& Andini, R. (2016). PENERAPAN METODE ACTIVITY BASED COSTING SYSTEM DALAM MENENTUKAN TARIF JASA RAWAT INAP (Studi Kasus Pada Rumah Sakit Umum RA. KARTINI Kabupaten Jepara). In Journal Of Accounting (Vol. 2, Issue 2).

PUTRI, D. A. (2011). Analisis Penggunaan Metode Activity Based Costing Sebagai Alternatif Dalam Menentukan Tarif Spp Smp-Sma Pada Ypi Nasima Semarang Tahun 2010. 56.

Qurnain, N. (2011). Analisa Penentuan Tarif Jasa Rawat Inap dengan Menggunakan Activity Based Costing System (ABCS) di Rumah Sakit Paru Pamekasan. 1(01), 212.

Riwayadi. (2014). Akuntansi Biaya (Pendekatan Tradisional dan Kontemporer). Jakarta: Salemba Empat.

Rudianto. (2013). Akuntansi Manajemen Informasi Untuk 
Pengambilan Keputusan Strategis (S. Suryadi (ed.)). Penerbit Erlangga.

Satria, H. (2017). Penerapan Metode Activity Based Costing Untuk Menentukan Harga Pokok Produksi. Jurnal Benefita, 2(2), 92-101.

https://doi.org/10.22216/jbe.v2i2.1 265

Siregar, Baldric, dkk. (2013). Akuntansi Manajemen. Jakarta: Salemba Empat.
Siregar, dkk. (2014). Akuntansi Biaya. Jakarta: Salemba Empat.

Siregar, H. F., Sinaga, J., \& Elisabeth, D. M. (2017). PENERAPAN METODE ACTIVITY BASED COSTING UNTUK MENENTUKAN TARIF KAMAR HOTEL PADA HOTEL TOLEDO INN DI SAMOSIR. 7, 56-67.

Tunggal, A. W. (2003). Activity Based Costing Suatu Pengantar. Jakarta: Harvarindo. 